\title{
Justice as a Virture of Character
}

\section{S. Evan Kreider}

University of Kansas ${ }^{1}$

In this paper, I will discuss several difficulties raised by Aristotle's notion of justice as a virtue of character. I will then examine solutions to these difficulties as proposed by David Bostock, Bernard Williams, and Howard J. Curzer. I will conclude by arguing for my own solution, which is an attempt to improve upon Aristotle's doctrines by synthesizing and expanding upon the best aspects of the solutions put forward by the aforementioned scholars.

The basic tenets of Aristotle's ethics are familiar enough; therefore, a brief summary, mostly for the purpose of raising various issues, should suffice. According to Aristotle, a virtue is a state of character ${ }^{2}$ which is a mean between extremes. ${ }^{3}$ The mean in question is not a mathematical mean ${ }^{4}$ but rather an appropriate amount, at the appropriate times, in the appropriate circumstances, in the appropriate manner, etc. ${ }^{5}$ The two extremes on either side of this mean, one of excess and one of deficiency, are the corresponding vices. ${ }^{6}$

The discussion thus far naturally raises the question: a mean and extremes of what? There are at least two reasonable ways to interpret Aristotle's view on this. On one interpretation, the mean and extremes lie within a range of possible emotional responses. ${ }^{7}$ In some cases, this range appears to involve only one such emotion. For example, temperance ${ }^{8}$ is the mean of desire for pleasures of touch and taste which lies between the excess of self-indulgence and the deficiency of insensibility. In other cases, it appears to involve multiple inter-related emotions. For example, courage ${ }^{9}$ is the mean of fear and confidence which lies between cowardice, which is excessive fear and / or deficient confidence; and foolhardiness, which is deficient fear and / or excessive confidence.

David Bostock raises an interesting question regarding the virtues and vices and their related emotions: Are all the virtuesvice sets necessarily related to a particular emotion or pair of in- 
ter-related emotions, or can a single virtue-vice set involve emotions in a more general manner? For example, need honesty and its corresponding vices be associated with a particular emotion, or could the vice of dishonesty involve fear, pride, greed, lust, or any other number of emotions? ${ }^{10}$

For the moment, I will leave these questions unanswered. However, they should be borne in mind, as they will prove relevant when we discuss possible solutions, including one of Bostock's, to the various puzzles raised by justice as a virtue of character, especially with regard to its particular motivation, if indeed it has one.

Returning to means and extremes, another reasonable interpretation posits that, for at least some of the virtue-vice sets, the mean and extremes lie not within a range of emotional responses, but rather within a range of possible actions. " For example, generosity is the mean between giving too much (extravagance) and giving too little (stinginess). Virtues involve acting appropriately, and may or may not be associated with the emotions at all, much less any particular emotion or inter-related pair of emotions.

This interpretation raises some questions of its own. On this view, is the mean still a state of character? If so, what sort of state of character would it be? Would it be a disposition to act virtuously? If this is the case, then doesn't Aristotle's theory suffer from problems of circularity or incompleteness? Would an objective, determinate action-guiding principle of generosity (for example) be required in order to break the circle or complete the theory?

If it isn't already obvious from the blatant rhetorical force of the above paragraph, I'm personally not inclined to endorse this interpretation. However, I must admit that does have at least a little merit, especially when considering virtues such as generosity and honesty. This interpretation is held to some extent by Bostock, and so will also prove especially relevant to our discussion of his proposed solution to the difficulties raised by Aristotle's notion of justice as a virtue. However, in this case too I would like to leave these questions unanswered for now, asking the reader to keep them in mind, as they will be relevant when we do reach our later discussion of various solutions to the problems with justice. 
Let us return to our summary of the virtues. On Aristotle's account, each virtue is specified as narrowly as possible. For example, courage only concerns fear and confidence with regard to death in battle. Strictly speaking, courage does not involve fear or confidence regarding poverty, though these might be relevant to the virtue of generosity and its corresponding vices. Nor does courage involve fear or confidence regarding political dishonor, though these might be relevant to the virtue of proper ambition and its corresponding vices. ${ }^{12}$ These species of fear, and others like them, may be similar or analogous to courage, but are more properly ascribed to other virtue-vice sets such as the ones I've mentioned. In any case, Aristotle makes it clear that we should treat the virtues as narrowly as possible.

Now, at last, we turn to justice itself. Aristotle clearly treats justice as one virtue along side the others, at least in some sense. Consider the initial paragraphs of book five of the Nicomachean Ethics, which clearly imply that we should discuss justice in the same manner as the preceding discussions of the virtues of character. However, justice doesn't always fit the pattern of the virtues of character described above.

Some of these tensions are resolved once we recall the distinction between general (a.k.a. universal) justice and specific (a.k.a. particular) justice. According to Bostock, Aristotle's distinction between general and specific justice is meant to capture the ambiguity of the Greek terms dikaios and adikos. Aristotle's general sense of these terms is similar to our general usage of the words "right" and "wrong," especially insofar as we use these terms to characterize and evaluate our other-regarding actions. Aristotle's specific sense of these terms is similar to our words "just" and "unjust."13

Thus, Aristotle uses general justice to refer to complete virtue in relation to other people, ${ }^{14}$ where we simply mean the rightness of the virtues of character such as generosity, courage, etc., and the actions which flow from them, insofar as they involve others within our social-political context. General justice as a virtue of character is consistent with the doctrine of the mean and provides no serious difficulties to this doctrine, since general justice is simply a second-order virtue; that is, it supervenes on the other-regarding 
aspects of the other virtues of character. It does not require its own distinct domain of emotions, motives, goods, etc., since it borrows them from the relevant first-order virtues of character, and it involves a mean in the same manner as those first-order virtues. Therefore, general justice is no more troublesome to Aristotle's conception of the virtues of character or the doctrine of the mean than the first-order virtues upon which it supervenes.

So then it is specific justice which Aristotle takes to be another one of the first-order virtues of character. But what then is the domain of emotions, motives, goods, etc., over which specific justice reigns? Aristotle's own account is sketchy:

- Specific justice is concerned with goods of fortune with intrinsic worth but not necessarily good for the particular person who has them. ${ }^{15}$ These goods include honor, money, and safety; ${ }^{16}$ that is, divisible social-political goods. ${ }^{17}$

- Acts which violate our objective notions of specific justice may occur as the result of a variety of motives or vices, but the motive properly associated with specific justice as a vice of character is pleonexia. ${ }^{18}$

- Pleonexia involves wanting more; for example, more of the amount of goods distributed; or, if one is not a recipient of the goods distributed but is involved in the distribution process somehow (say, as a judge), more of the gratitude of the recipients or "to exact a penalty." 19

- Specific justice involves a mean between acting unjustly and being treated unjustly. ${ }^{20}$

- Specific justice is a different sort of mean than the means of the other virtues of character, in that it aims at the mean. ${ }^{21}$

Here are just a few of the many possible difficulties raised by the above statements:

- Aristotle only gives us one vice (pleonexia) not two, therefore the doctrine of the mean is violated.

- Aristotle only characterizes specific justice negatively, via specific injustice and pleonexia. Specific justice does not have any positive content and is therefore not a substantial 
mean, as with the other first-order virtues of character. Thus, specific justice does not fit Aristotle's general scheme for the virtues of character nor the doctrine of the mean.

- Since each virtue-vice set involves its own unique motivation, the motives involved in specific justice cannot overlap with those of any other virtue-vice set, such as generosity. However, this seems absurd, since common sense tells us that the same motive (for example, monetary greed) could be behind both stinginess and specific injustice (for example, unfairly distributing wealth).

- On a related note, pleonexia might be the motive behind many instances of specific injustice but isn't necessarily so; for example, apathy or mischief might also motivate one to distribute goods unjustly.

- Also, pleonexia does not appear to be its own distinct emotion or motive, but rather a general term for a class of emotions such as monetary greed, over-ambition, etc. Thus specific justice does not have its own distinct emotion, and therefore is not a distinct first-order virtue of character.

- Aristotle's claim that specific justice involves a mean between acting unjustly and being treated unjustly ${ }^{22}$ is obviously a weak attempt to force specific justice into the constraints of the doctrine of the mean, especially since its not clear that being treated unjustly could be a vice. ${ }^{23}$

There are a variety of possible solutions to such difficulties, a few of which we will now consider:

One possible solution is simply to deny that specific justice is a virtue of character. We might claim that Aristotle was wrong to say so, and is then forced to resort to several artificial arguments and claims in order to force specific justice into his model for the virtues of character and the doctrine of the mean. Instead, we should simply let general justice be the unproblematic second-order virtue of character and treat specific justice as an independent political principle for legislation and lawful action, which ultimately coheres better with his discussion of specific justice in distribution, rectification, exchange. 
However, this solution is inadequate. It is contrary to common-sense moral intuitions that people can express the character traits of justice and injustice, and in more than a mere secondorder way. Aristotle takes great pains to make his theories compatible with common-sense morality insofar as possible, so this solution would be a bit of a philosophical cop-out.

Another possible solution notes that specific justice does not fit the pattern of the typical virtues of character, for many of the reasons above. However, some of the virtues of character themselves do not fit the model for the virtues of character. Though it's true that some virtue-vice sets (for example, temperance and courage, and their associated vices) are associated with a single emotion or pair of inter-related emotions, others are related to the emotions in a more general way (for example, honesty and specific justice). Therefore, Aristotle should actually have three classes of virtues instead of two: virtues associated with a particular emotion, virtues associated with the emotions in a more general way, and virtues associated with reason (that is, the intellectual virtues). The account of the virtues which Aristotle gives, including the doctrine of the mean, is more or less sufficient for the virtues associated with particular emotions, but he needs to come up with a different account for the virtues associated with emotions more generally, just as he gives a different account for the intellectual virtues. Aristotle himself probably recognizes this in his discussion of specific justice and the difficulties which he himself raises. ${ }^{24}$

I'm more sympathetic to this solution than the first. I think it's on the right track, especially since it does appear that specific justice needs a somewhat different account than virtues such as courage or generosity, for all the reasons we've already discussed. However, I believe it's possible to go further than this, and give an account which brings specific justice at least somewhat more in line with the more typical virtues of character, as we shall see.

Another possible solution, one put forward by Bernard Williams, is to flatly deny that specific justice fits the pattern of the other virtues of character and the doctrine of the mean. First of all, Aristotle gives us only one vice, not two. Also, Aristotle is just plain wrong to claim that pleonexia is necessarily associated with every instance of specific injustice. Furthermore, pleonexia is not 
a distinct emotion, but at best a non-technical term used to refer to a whole class of relevant emotions. However, specific justice can be characterized by the motive to justice itself. Unlike the other virtues, where the objects are money, honor, etc., and the person is called virtuous insofar as they are disposed towards these objects appropriately, specific justice itself can serve as the object of the just person's actions and deliberations. The virtue of justice is simply a disposition to act justly, which in this case is not circular or incomplete, since Aristotle goes on to give an independent account of specific justice in terms of distribution, rectification, exchange, and the principles behind each. The disposition to justice involves resisting any of a whole class of motives which would otherwise steer one away from justice (for example, monetary greed, overambition, etc.), which Aristotle carelessly refers to as pleonexia, though it could in fact involve other non-"greedy" motives. ${ }^{25}$

I believe that this solution takes us one step closer to the best possible solution, but does not take us all the way. I more or less agree with William's characterization of the motives behind justice and injustice, and his take on pleonexia. However, Curzer also gives some interesting suggestions which not only provide a notion of specific injustice more consistent with the doctrine of the mean, but also provides a more positive and substantial account of specific justice and injustice, as well as pleonexia.

According to Curzer, Aristotle gives or at least implies a fuller account of specific justice which does fit the model of the virtues of character and the doctrine of the mean. Specific justice (and its associated vices), like courage (and its associated vices), actually involves two inter-related ranges of emotion. The first emotional range has the excess of pleonexia (the illicit desire for goods qua unjustly distributed / undeserved), the implied ${ }^{26}$ deficiency of meionexia (the masochistic desire for less than one deserves), and a mean (the desire for goods qua all and only what one deserves). Aristotle's account is further completed if we bring in his notion of nemesis, the mean desire for others to get what they deserve (opposed to the vices of spite and envy). ${ }^{27}$

In my considered opinion, Curzer comes closest to the correct solution to the problems of specific justice as a virtue. I especially like the form of Curzer's account, wherein there are two inter- 
related motives, one self-regarding, one other-regarding. However, I'd prefer to use something more like William's characterization of the content of the motive behind justice. Then we get a virtue of specific justice which involves, at least in part, an appropriate desire for justice, both for one's self and more generally, and it is possible to go wrong either in excess or deficiency with regard to either. A few examples of each:

Excess regarding self: wanting more of the socially-distributed goods than one deserves; so pettily pursuing what one is owed that one fails to take into account other morally relevant considerations.

Deficiency regarding self: not pursuing what one justly deserves; not sticking up for one's self.

Excess regarding others: vengeance; vigilantism.

Deficiency regarding others: distributing goods unfairly from mere apathy or frivolity.

In this way, we have a positive notion of the virtue specific justice and the two corresponding vices of specific injustice with distinct objects and motivations which cohere with the doctrine of the mean and which preserve our moral intuitions regarding the proper ascription of just or unjust to a person's character and motives. Though this isn't exactly Aristotle, it's an improvement which I think he himself would have appreciated.

\section{Notes}

' This paper was first presented at the Kansas Philosophical Society meeting at Washburn University in Topeka, Kansas on February 15, 2003.

${ }^{2}$ Aristotle, Nicomachean Ethics (hereafter NE), trans. David Ross, rev. ed. (Oxford: Oxford University Press, c1954), 1106a13.

${ }^{3}$ Aristotle, NE 1106b17; 1107al.

${ }^{4}$ Aristotle, NE 1106a27; 1107a1-2.

${ }^{5}$ Aristotle, NE 1106b17-24.

${ }^{6}$ Aristotle, NE 1107a3-4.

${ }^{7}$ Also sometimes characterized as desires or motives.

${ }^{8}$ Aristotle, NE 1117b24-1119b22.

${ }^{9}$ Aristotle, $N E$ 1115a8-1117b23.

${ }^{10}$ David Bostock, Aristotle's Ethics. Oxford: Oxford University Press, 2000, 49. 
${ }^{11}$ Bostock, Aristotle's Ethics 45-50.

${ }^{12}$ Aristotle, NE 1116a17-1117a29.

${ }^{13}$ Bostock, Aristotle's Ethics 54-55.

${ }^{14}$ Aristotle, NE 1129b31-35.

${ }^{15}$ Aristotle, $N E 1129 \mathrm{b3}-5$.

${ }^{16}$ Aristotle, $N E 1130 \mathrm{~b} 3$.

${ }^{17}$ Aristotle, NE 1130b31-32.

${ }^{18}$ Aristotle, NE 1129a25-35.

N.B.: Aristotle clearly makes a distinction between virtuous and vicious acts on the one hand, and virtuous and vicious agents on the other. The later must involve a certain state of character. Thus, to properly characterize someone as having a specifically unjust character, rather than having a merely cowardly character (for example) which incidentally results in actions which violate our notions of specific justice, the agent must have a vicious state of character / motive which Aristotle identifies as pleonexia.

${ }^{19}$ Aristotle, $N E$ 1137a2. By "to exact a penalty," I take it that Aristotle has something like vengeance in mind.

${ }^{20}$ Aristotle, NE 1133b30-33.

${ }^{21}$ Aristotle, $N E$ 1134al-2.

${ }^{22}$ Aristotle, NE 1133b30-33.

${ }^{23}$ On a charitable note: in context, this last of Aristotle's statements seems to indicate his own awareness of these difficulties, rather than a disingenuous attempt to artificially construe specific justice in such a way as to fit the pattern of the other virtues of character or the doctrine of the mean.

${ }^{24}$ This solution is essentially that put forward by David Bostock in chapter 3 ("Justice") of his book Aristotle's Ethics. Oxford: Oxford University Press, 2000.

${ }^{25}$ Bernard Williams, "Justice as a Virtue" in Essays on Aristotle's Ethics, eds. Rorty, Amelie Oksenberg. Berkeley, Calif.: University of Califormia Press, c1980, 189-199.

${ }^{26} \mathrm{Cf}$. $N E$ 1123a35-1125b27 re: virtues associated with honor.

${ }^{27}$ Howard J. Curzer, "Aristotle's Account of the Virtue of Justice" in Apeiron 1995; 28(3): 207-238. 